\title{
Monetary Policy and Central Bank Independence in a Former Communist Country; Curious Evolutions in Romania
}

\author{
Irina Mădălina Doroftei and Cristian Păun
}

\author{
The Bucharest University of Economic Studies, Department of International Business and \\ Economics, Bucharest, Romania
}

Correspondence should be addressed to: Irina Mădălina Doroftei; madalina.doroftei@gmail.com

Received date: 23 April 2013; Accepted Date: 17 May 2013; Published Date: 13 August 2013

Copyright (C) 2013 Irina Mădălina Doroftei and Cristian Păun. Distributed under Creative Commons CC-BY 3.0

\begin{abstract}
The subject of central bank independence has been the focus of debates during the 1990s and 2000s. It seems that consensus has been reached over the need to support high legal central bank independence in order to achieve price stability, and lower inflation rates. However, many doubt this institutional arrangement has the desired outcome in all cases and fear that cultural elements such as inflation aversion among citizens, tradition of rule of law and other factors may be more important. Romania, as member of the European Union, has to comply with the high legal central bank independence requirements. Despite the alleged progress of the National Bank of Romania, concerns regarding its real independence from the government still remain. The article explores the development of central bank independence in relation to monetary policy, in the case of Romania.
\end{abstract}

Keywords: central bank independence, monetary policy, inflation targeting, government debt

\section{Introduction}

The evolution of central banking is well known and documented. Besides the main purposes of financing wars and public debts, the forerunners of modern central banks were chartered by rulers/parliaments/governments sometimes to better accommodate and integrate newly founded states (as in the case of Germany, as Goodhart (1991) mentions, or that of Italy as Siklos (2002) remarks). The grounds for monopolizing the trade of money creation by one institution, finally subordinated to the state and presently (with few exceptions) stateowned $^{1}$, include the status of money as public good, the belief that money must be issued through a noncompetitive, nonprofit-maximizing process and so on. This

Cite this Article as: Irina Mădălina Doroftei and Cristian Păun (2013), "Monetary policy and central bank independence in a former communist country; Curious evolutions in Romania" Journal of Eastern Europe Research in Business and Economics, Vol. 2013 (2013), Article ID 165597, DOI: 10.5171/2013.165597. 
is the modern explanation that one will find in many books. But throughout history, most of the predecessors of central banks were given monopoly over note issuing (and thus money creation) and other advantages in return for financing the public debt. Even more important, the monetary privileges were given to private entities that did operate to their own profits, independent of the government's control. Starting with the process of debasement, governments discovered the power of inflation, money creation and debt monetization - inflation meant seigniorage profits, lower real debt etc., and a form of taxation that could hardly be avoided - and wished to use it to their own benefit. Slowly, they gained a certain degree of control by renewing the banks' charter on condition they purchase government bonds (as in the case of Bank of England or Banque de France, Goodhart (1989)).

The First World War showed that governments used their central banks to finance the war through inflationary monetary policy. As a result, the new central banks that were established and many of the old ones that were reorganized complied with the programme of reconstruction discussed at the Brussels and Genoa conferences. The latter contained the proposal that independent central banks against government be established. In Whale's (1939) words: "Largely the object may be said to have been to restore the status quo ante bellum." The League of Nations applied the scheme in Europe, while various personalities advocated it on other continents. The concept of independent central bank was also incorporated in text books such as the one of Kisch and Elkin.

The Great Depression and World War II brought an end to the idea of central bank autonomy. Governments took over monetary policy in times of intense crisis and the spreading of socialism, interventionism, as well as the success of Keynesianism had a major contribution to the changing status of central banks - most of them became state-owned or state- controlled. During the inflations of the 1960 s to 1980 s the idea did return, that a central bank less influenced by government would maintain a lower inflation rate.

The modern rationale for central banking (i.e. supply a public good, etc.) came afterwards and many monetary authorities have been established in the 20th century based on those grounds and on the institutional trend in the entire world. In Capie's view (2009), today's modern central banks have adjusted to the environmental changes around them and the more newly established ones have been designed under the supervision of the state. As "creatures of the state", central banks' relationships with the governments in different countries have been shaped not only by legislation, but also by history, tradition and personalities heading them, having an impact on their institutional design (Siklos, 2002). Thus, the role played by central banks and their performance is highly influenced by politics.

Leaving aside the fact that in most of the industrialized countries the seigniorage profits go to the state (Siklos, 2002), the government and the central bank each operate crucial public policies (which can have enormous impact on the economy) the fiscal policy, and, respectively, the monetary policy. The two are linked through the government sector's budget constraint, according to Walsh (2003). A clear distinction between the two above has been intentionally made in the pursuit of emphasizing the separation between them. Although some central banks are part of the government, in the 1990s a widely developed and discussed concept has re-emerged: central bank independence. It is seen as an institutional arrangement that could have as a result the reduction of high and persistent inflation (Cukierman, 2008). Moreover, many authors, like Blinder in 1998, have come to assume in their analysis that central banks are, indeed, independent of the governments' political pressure. Nowadays, most of the central banks in both developed and developing countries have gained a certain degree of autonomy 
in conducting monetary policy, at least formal, through their statutory charter. Therefore, the following questions arise: what is exactly central bank independence (CBI)? And how did it come to carry such great importance in the institutional design of monetary authorities? Is it really effective? Sections 2 and 3 survey the literature on the subject, while sections 4-8 assess the Romanian central bank's performance in the last 20 years and the relevance of central bank independence in carrying its activities.

\section{Central bank independence definition}

Central bank independence can be generically defined as the right to conduct monetary policy without being contested by or having to consult with the government (Capie, 1995). Others (Bordo, 2008) see it as the "noncooperation between fiscal and monetary authorities in policy implementation". For Blinder (1998) it means that "the central bank has freedom to decide how to pursue its goals" and "its decisions are very hard for any other branch of the government to reverse”. In Walsh's words (2008), „Central Bank Independence refers to the freedom of monetary policymakers from direct political or governmental influence in the conduct of policy". But Siklos (2002) makes an important observation: central bank autonomy can only occur within government and fiscal and monetary policy cannot be entirely separated. Furthermore, he considers monetary policy as a joint responsibility of both central banks and governments. Eijffinger and De Haan (1996) record the first attempts to assess the usefulness of an autonomous monetary authority in Friedman's work at the beginning of the $1960 \mathrm{~s}^{2}$, where central bank autonomy in relation to the government is similar to the one between the judiciary and the government. Eijffinger and De Haan (1996) find throughout the literature review, that the concept is given three directions: independence in matters that relate to personnel ${ }^{3}$, financial independence ${ }^{4}$ and policy independence with respect to goals (whether a central bank decides which are the final goals of the monetary policy or not) and with respect to instruments (whether the central bank can use whatever means it finds most appropriate in order to achieve its goal(s) or not).

Hence, one may conclude that central bank independence involves more or less the conduct of monetary policy without the interference of politicians. But the need for central bank autonomy happened as a consequence of mistrust in politicians, and thus governments, to operate the monetary policy to the benefit of society and to operate the fiscal policy in a disciplined manner. Several theoretical and empirical studies demonstrated that politicians have short-term plans and seek to bust the economy before elections in order to be reelected - by controlling monetary policy and inflating the economy they can give the impression that the economy is prospering during their end of term. Even in the absence of political cycles, the temptation is to behave opportunistically and reach for short-term gains at the expense of the future. But an independent central bank would assure a low inflation. Therefore the recommendations comprised that an autonomous institution be founded that could outcast the political influence, by considering the long term, and were included in national legislation. Also, because the public and the governments have little patience, this monetary authority would be given independence in such a manner as to credibly pursuit price stability on the long run.

The fundamentals supporting the modern concept of central bank independence are considered to be the time-inconsistency models of Kydland and Prescott (1977) and Barro and Gordon (1983). The first two reached the conclusion that private agents and policymakers are influenced in their decision-making by expected future policies and reactions to them. As a result, choosing the best decision given a current situation delivers suboptimal results or even economic instability over a longer period of time. That is why (predictable) rules are better than discretionary policy. Barro and Gordon (1983) considered that discretion gives worse results than rules. But better results are delivered when policymakers use their reputation and 
cheat when people anticipate the rule. They demonstrated that obtaining a low inflation contributes to building a reputation which will be later used by policymakers in order to achieve a surprisingly high inflation. The above theory brought to light the inflationary bias and, thus, the sub-optimal high inflation that the government delivers. This doesn't mean that central bank independence didn't exist before. As we have seen, central banks were private and independent until the 20th century, they came under the control of the government by the mid of the 20th century and the concern for independence and price stability re-emerged latter on in the 20th century.

Rogoff (1985) completed the theory by explaining why so many countries had instituted independent central banks headed by conservative governors in recent years. His model demonstrated that society will be better of if a 'conservative' central banker is in charge of monetary policy - meaning that he or she puts greater weight on inflation stabilization to the detriment of employment stabilization than society does 5 . This would lead to a lower level of inflation, with smaller social costs. But the appointment of a conservative monetary authority was his third-best solution: the first one implied that labor market distortion be eliminated, and the second-best solution was to 'legally impose a complete state-contingent money supply rule'.

Even though the three well-known above mentioned articles did not clearly state the need of improving the autonomy of central banks, Rogoff (1985), who considered the monetary authority to be already independent ${ }^{6}$ did make one suggestion (the only one in the article who can be related to $\mathrm{CBI}$ ):

'The same model can be employed to explain many of the measures that countries take to insulate their central banks from inflationary pressures. For example, central banks are often endowed with a significant measure of political and fiscal independence. The analysis also suggests why it would be desirable to have a central bank's operations financed in such a way that its expenditures are independent of the government's seignorage revenues.' (p.1180)

In the following years many academics produced empirical evidence on whether central bank independence helps to reduce inflation and inflation variability, influences output variability etc., or not. The conventional wisdom became that granting independence to central banks leads to an institutional arrangement that avoids policymakers' opportunistic behavior and results in lower average inflation. The most important signal was given by the design of the future European Central Bank in 1990, by publishing the Draft Statute of the European System of Central Banks and of the European Central Bank: With an Introductory Report and a Commentary, followed by the Treaty on European Union (also known as the Maastricht Treaty) in 1992, both incorporating important specifications regarding central bank autonomy. Public authorities in the entire world understood that this was the future approach to monetary policy.

\section{Central Bank Independence and Monetary Policy}

Eijffinger and de Haan (1996), Berger et al (2001), Cukierman (2008) and Hayo and Hefeker (2010) have all researched and documented a consistent literature review on the subject. The results have been somewhat inconclusive. The general consensus is that central bank independence (coupled with a clear mandate for the central bank to achieve price stability) is negatively correlated to inflation, without having any impact over output variability, at least in developed countries. The relation of causality between the two has been several times questioned, and the robustness of the previous studies reexamined. Some academics have suggested that the correlation between the two could be a result of a third factor, the culture and tradition of monetary stability - the way 
the public perceives and demands price stability (its social choice or national inflation culture in Hayo and Hefeker's (2010) words) and the history of institutions. The fact that the same index used to measure legal CBI does not provide significant results in the case of developing countries and that, even more, the transition countries have known higher inflation rates even though the CBI was legally increased, shows that political culture is indeed an important element in the equation. Some studies have even claimed the opposite - that there is a negative correlation between low inflation and legal independence (Hayo, Hefeker, 2010). But research using the latest update of CBI index, which compares the evolution between 1980-1989 and 1990-2003 of central bank independence and inflation shows that there is an inverse relationship between the two variables in transition countries located in Central and Eastern Europe (Crowe, Meade 2007).

\section{Central Bank Independence in Romania}

Romania, as former communist country, experienced a totalitarian regime based on central planning. After the fall of communism it struggled to organize itself as a democracy and to develop a market- oriented economy. Its central bank, the National Bank of Romania (NBR herein), has known several reforms and its charter changed accordingly in January 1991, in May 1998 and in June 2004.

Using a central bank independence (CBI) index for measuring legal independence of central banks (CWN herein) developed by Cukierman et al. (1992) and consulting several specialised articles that provide valuable historical data (Cukierman et al., 1992; Neyapti 2001; Crowe and Meade, 2007) we reach the conclusion that legal independence of the NBR has considerably increased (Fig.1). The 2012 CWN is according to the authors' calculations while the other values of $\mathrm{CWN}$, based on the same methodology, have been collected from the published work mentioned above. The evolution of legal central bank independence is strongly related to the reforms enacted in NBR's charter. Law no. 34/1991 made the central bank even more dependent of its politicians, while Law no. $101 / 1998$ improved its legal independence. The EU accession and the envisaged Euro system membership had a decisive role in improving the independence of the NBR together with its charter last modified by Law no. 312/2004.

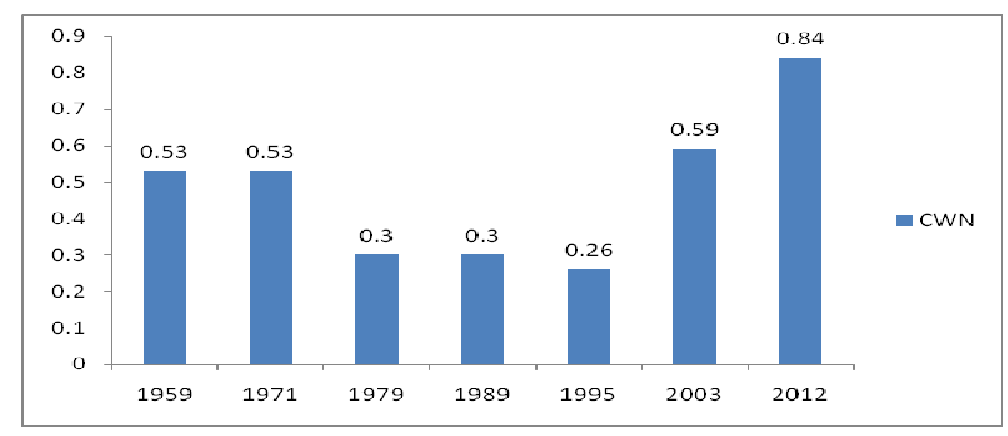

Fig.1: Central Bank Independence of the National Bank of Romania 


\section{Central Bank Independence and Performance}

Over a long period of time, it would seem that inflation has been well fought against once the independence of the NBR has been increased (Fig.2). No need to mention that during communism all prices were controlled, therefore the inflation was nearly zero in those times. The transition from a planned economy to a marketoriented one was unsurprisingly accompanied by high inflation with two peaks - one in 1993 (256\%) and in 1997 (154.8\%). Starting with 1998, Romania registered falling two-digit inflation and after 2004 it remained at one-digit inflation. The performance was accredited to the new Law no. 312/2004 which increased the independence of the NBR, and to the introduction of direct inflation targeting in August 2005.

Fig.2: Central Bank Independence and Inflation in Romania

Only after the inflation targeting regime had become the monetary policy strategy of the NBR, did the inflation decline to a one-digit number. The targets were set after consulting with the Romanian government. Still, NBR's performance in hitting the target is somewhat inconclusive (Fig.3). Most of the time NBR missed the target ( 6 out of 8 years) and inflation often recorded levels outside the variation band (Lower and Upper Limit).

The literature on the subject of central bank independence concludes that higher central bank independence will be conducive to lower inflation and lower inflation variability in the case of developed countries. The above figure shows that, although NBR has de jure independence, uncertainty still reigns in Romania when it comes to inflation. An explanation may be that, as many studies researched, the CWN is not illustrative for the degree of de facto central bank independence in developing countries. A measure of central bank independence meant to illustrate de facto independence is the turnover rate of central bank governors (Cukierman et al., 1992). In the case of Romania, one may not decide on its level as the NBR governor has been Mugur 
Isărescu, Member of the Romanian Academy, from 1990 till present times.

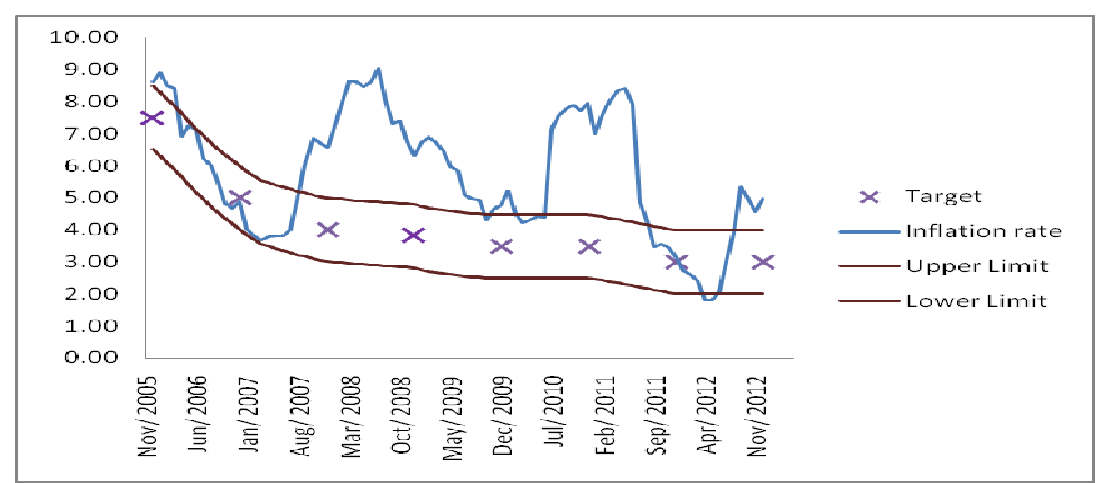

Fig.3: Inflation targeting (\%p.a.)

\section{Central Bank Independence and Credibility}

Siklos (2008) takes into consideration core elements that define CBI, one of them being a proxy for monetary policy credibility materialized in accumulated inflation forecast errors. He uses data from the World Economic Outlook (WEO) to evaluate on an annual basis the inflation forecast errors based on the following formula:

$$
\mid \text { cumsurp } p_{1}\left|=\sum_{t=1991}^{2004}\right| \pi_{t}-\pi_{t}^{W E O} \mid=3.883
$$

The authors follow the same methodology for the period 2005-2012 and reach an interesting conclusion. During 1991-2004, when the NBR was more dependent on the government, the accumulated inflation forecast errors rose to 3.88 points. In comparison, for the years 2005-2012, when the NBR was allegedly less dependent on the public authority and its legal independence increased considerably, the same proxy for credibility of monetary policy was 11.059 points.

$$
\mid \text { cumsurp }\left|=\sum_{t=200 \mathrm{~s}}^{2012}\right| \pi_{t}-\pi_{t \mid t}^{W E O} \mid=11.059
$$

The conclusion may be that while the NBR increased its de jure independence, the delivered inflation deviated from the forecasts more severely as compared to its past, contrary to expectations and theoretically harming its credibility. Still, the National Bank of Romania finds itself on the first place when it comes to trust Romanians do not trust the government and its institution, nor the parliament or the judicial. Instead, the NBR is highly regarded as being a solid, uncorrupted and trustworthy institution, in spite of its poor performance.

\section{NBR's Monetary Policy}

The direct inflation targeting regime adopted by NBR offers a framework for monetary policy in which the central bank uses its instruments in order to maintain the inflation in the variation band. As we have seen in a previous section, NBR has had a poor performance in achieving the targeted inflation. Plus, having more legal independence has meant accumulating even more errors of deviation from the forecasted inflation. Or, the other way round, it may be that the high de jure independence isn't doubled by a high de facto independence. 
If we analyze the relationship between inflation and the key policy rate, it should be obvious a relationship between the two, since NBR uses inflation targeting as its monetary policy strategy. The same should be for the relationship between inflation and monetary aggregate M1, another monetary policy instrument. But figures 4 and 5 show another reality. In a simple regression the monetary policy instrument doesn't seem to depend on inflation forecasts or targets.

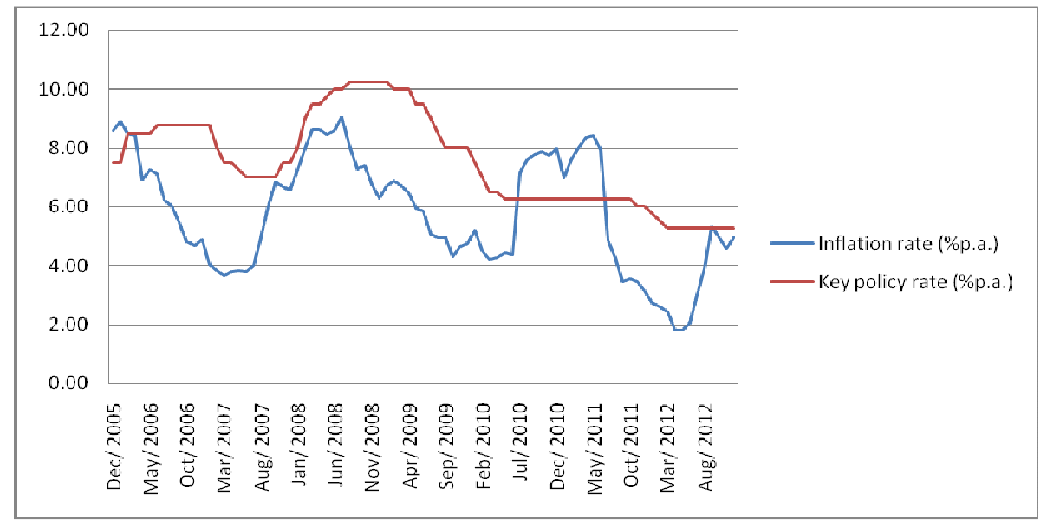

Fig.4: Inflation versus Key policy rate

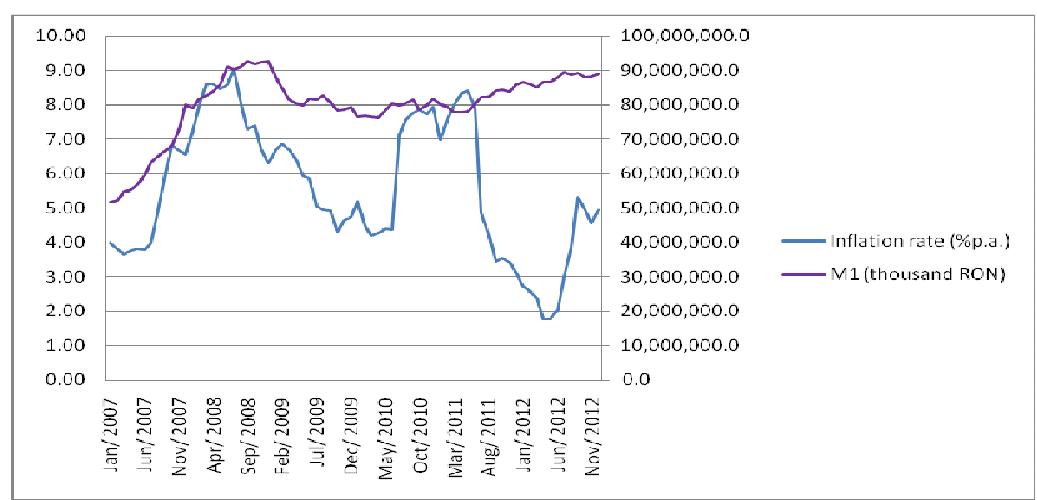

Fig.5: Inflation versus Monetary Aggregate M1

Irina Mădălina Doroftei and Cristian Păun (2013), Journal of Eastern Europe Research in Business and Economics, DOI: 10.5171/2013. 165597. 
Instead, it would seem that the National Bank of Romania is closely following the exchange rate EUR/RON and making its monetary policy decisions according to the evolution of the exchange rate (ER) as Fig. 6 shows. In other words, monetary policy instruments could be defined in a simple equation as $\boldsymbol{M P I}_{t}=\alpha+\boldsymbol{\beta}\left(\boldsymbol{\pi}_{t}-\boldsymbol{\pi}_{\text {target }}\right)+\boldsymbol{\mu}$ $\left(E R_{t}-E R_{\text {target }}\right)+\varepsilon$

If we eliminated the exchange rate variables, $\beta$ would be close to zero, meaning that inflation is actually statistically insignificant for the monetary policy instruments; a strange result for a central bank that officially undertook a direct inflation targeting regime.

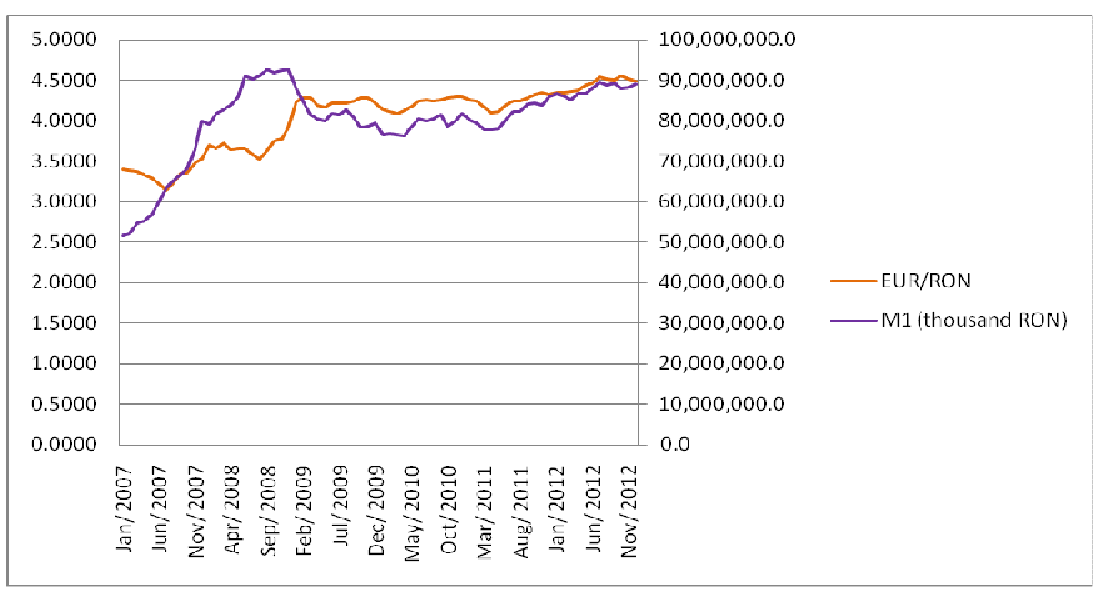

Fig.6: Exchange rate EUR/RON versus Monetary Aggregate M1

\section{Conclusions: NBR and Government Borrowing}

Leaving aside the fundamental objective of price stability, another purpose of an independent central bank is to conduct its activities with a small regard to government policy objectives, as long as they don't conflict with the central bank's main objective of maintaining price stability. Romania has a long history of corruption and irresponsible governments after the fall of communism. Therefore, the main interest is that NBR act as less dependently of the public authorities as possible. The main public perception is that NBR is a highly independent central bank, but a more critical point of view may reveal a slightly different situation.

In the first years after the fall of communism, the central bank used to lend the government when in need, in the limit of $10 \%$ of expected government expenditure. Today central bank direct credit to public authorities is prohibited by law. Although NBR considerably increased its legal independence after 2004, there are some problems remained unresolved.

For example, according to law, NBR transfers $80 \%$ share of the net revenues to the State budget on a monthly basis and makes adjustments after the closure of the 
financial year. This could amount to an intra-year credit, depending on certain circumstances. The fact is we cannot verify the degree in which this affects the central banks' independence and the results of such policy measures, as the information available to the public concerns only reports on the activity of NBR and government budget execution published on a yearly basis.

Another issue is that, according to the central bank charter, although NBR is prohibited from lending to the government, it may grant loans to majority State-owned credit institutions in the same way as any other eligible credit institution. Yet, this information is missing also from the public reports. Since 1990 the public debt of Romania has continually increased, reaching a level of $37.8 \%$ of GDP in 2012 . The government issues securities on the primary market several times a month and usually manages to raise funds successfully.
In recent years the National Bank of Romania has started to actively conduct open market operations: since 2008 Q4 it provides liquidity through repo operations (NBR buys eligible assets from credit institutions upon their commitment to repurchase the assets at the date and price agreed) while reverse repo operations, with the purpose of mopping up excess liquidity, were used between June 1997 and 2008 Q3. While in 2009 NBR conducted 23 repo operations, with various maturities up to 31 days, the average maturity since then has been 7 days. In 2010 there were 5 repo operations, 24 in 2011 and in 2012 NBR managed 53 repo operations. At the same time the government borrowed massively by issuing securities.

The following scattergram (based on 88 cumulated observations) shows the relationship between the subscribed amounts for government securities (only RON) and the repo operations - awarded amounts of RON in 2012.

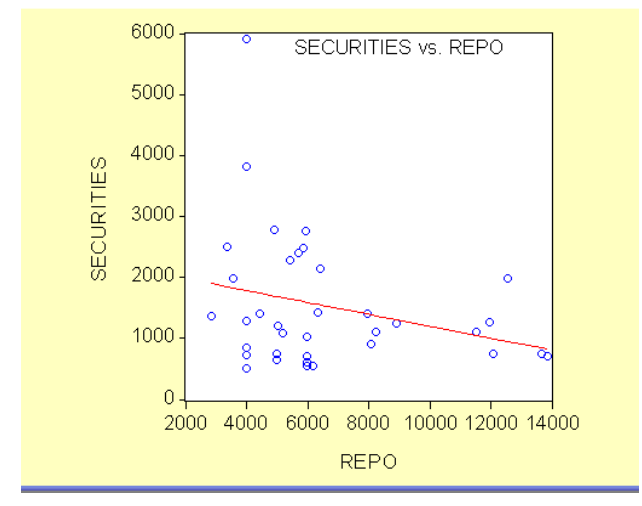

Fig.7: Government Securities versus Repo operations in 2012

Figure 8 illustrates the same information as the previous figure. We can infer a certain degree of relationship between the liquidity supplied by the NBR to credit 
institutions and the amounts of the latter bid for government securities. The National Bank of Romania must certainly know that it indirectly finances the Romanian government. In 2012, when Romania experienced 3 new governments with serious problems of financing its public spending, NBR conducted weekly repo operations, as compared to previous years, when open market operations were noticeably less used.

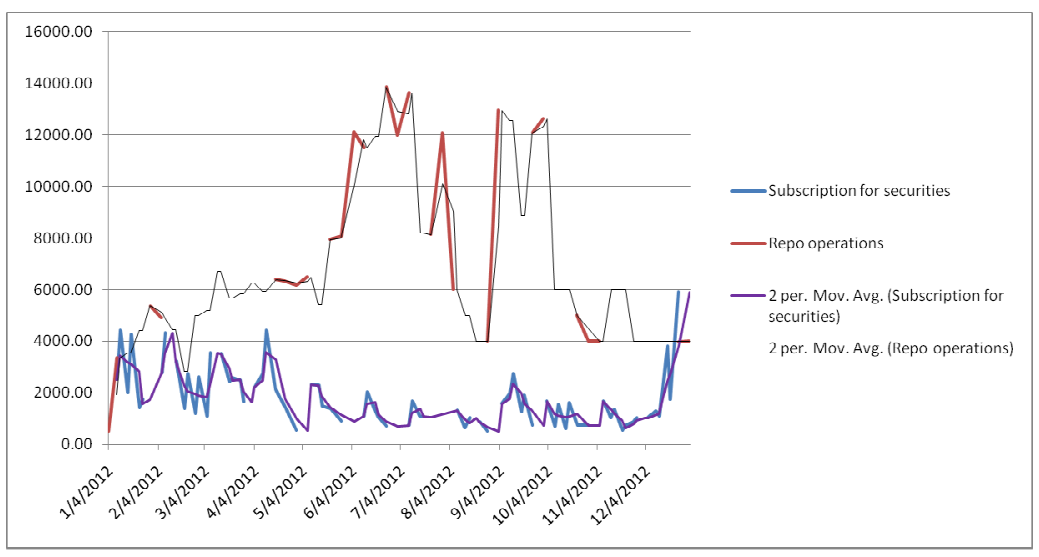

Fig.8: Government Securities versus Repo operations in 2012 (2) (mil RON)

In conclusion, it may seem that the Romanian central bank substantially increased its legal central bank independence in the last years, managing to improve its performance in fighting inflation as well. This doesn't come as a surprise, as NBR has to comply with the Euro system provisions. The success in reducing inflation may be awarded to the adoption of a direct inflation targeting regime, but inflation variability is still present.

A certain curiosity arises from the fact that NBR, together with its governor, is the most credible institution in Romania (and the most credible public personality), despite its failure to achieve the target inflation rates and the objective of price stability. Rather, it seems more focused on the evolution of the exchange rate, which concerns other public authorities also. The NBR has managed to maintain its high reputation by furthering the idea that monetary policy is a complicated subject, entrusted to experts and kept out of politics, incapable of being judged by non experts. The absence of certain available public information, as well as the incomprehensible conduct of monetary policy (it officially targets inflation as primary objective, but in fact is more exchange rates sensitive) may come to confirm the previous observation.

NBR longstanding governor and the recent evolution of government debt, correlated with open market operations, may raise doubts regarding NBR's de facto independence. As Friedman (1962) pointed out, policy is made highly dependent on personalities and the system based on CBI 
becomes a"system of rule by men and not by law". It may be as well being the case for Romania.

\section{Acknowledgment}

This work was co-financed from the European Social Fund through Sectoral Operational Programme Human Resources Development 2007-2013, project number POSDRU/107/1.5/S/77213 Ph.D. for a career in interdisciplinary economic research at the European standards" and from Research Project Number TE - 340.

\section{Notes}

1 in many cases central banks have been nationalized after World War II, in Siklos' (2002) account.

2 Friedman, M. (1962), Should There Be an Independent Monetary Authority, In Search of a Monetary Constitution, Yeager, L. B. (ed), Harvard University Press, Cambridge MA.

3 the role of government in appointing (and dismissing) members of the central bank governing board etc.

4 It refers to lending to public-sector authorities - if the government can borrow directly or indirectly from the central bank, it undermines its independence.

5 The weight is not infinite and the 'conservative' central banker does not care 'too little' about unemployment.

6 'We demonstrate that society can make itself better off by selecting an agent to head the independent central bank who is known to place a greater weight on inflation stabilization (relative to unemployment stabilization) than is embodied in the social loss function $A^{\prime}$ (p.1177)

\section{References}

Barro, R.J. and D. Gordon. (1983), 'Rules, discretion, and reputation in a model of monetary policy', Journal of Monetary Economics, 12(1), 101-121.

Berger, H., de Haan, J. and Eijffinger, S.C.W. (2001), 'Central bank independence: an update of theory and evidence', Journal of Economic Surveys, 15(1), 3-40.

Blinder, A. (1998), Central Banking in Theory and Practice, MIT Press, Cambridge MA.

Bordo, M. (2008), Monetary policy, history of, The New Palgrave Dictionary of Economics, Second Edition, Durlauf, S.N. and Blume, L.E (eds), Palgrave Macmillan, Houndmills.

Capie, F. (2009), Some scattered thoughts from history on evolution and design in central banking, Designing Central Banks, Mayes, D. and Wood, G. (eds), Routledge, Abingdon.

Crowe, C., and Meade, E.E. (2007), 'The evolution of central bank governance around the world', Journal of Economic Perspectives, 21(4), 69-90.

Cukierman, A. (2008), 'Central bank independence and monetary policymaking institutions - Past, present and future', European Journal of Political Economy, 24(4), 722-736.

Cukierman, A., Webb, S.B. and Neyapti, B. (1992), 'Measuring the independence of central banks and its effect on policy outcomes', World Bank Economic Review, 6(3), 353-398.

Eijffinger, S.C.W. and de Haan, J. (1996), 'The political economy of central-bank independence', Princeton Special Papers in International Economics, No. 19, Princeton University Printing Services, Princeton. 
Friedman, M. (1962), Should There Be an Independent Monetary Authority, In Search of a Monetary Constitution, Yeager, L. B. (ed), Harvard University Press, Cambridge MA.

Goodhart, C. A.E. (1989), What do Central Banks Do? in The Central bank and the financial system, 1995, Macmillan, Houndmills London.

Goodhart, C. A.E. (1991), The Evolution of Central Banks, MIT Press, Cambridge MA.

Hayo, B., and Hefeker, C. (2010), The complex relationship between central bank independence and inflation, Challenges in central banking, Siklos, P.L., Bohl, M.T. and Wohar, M.E. (eds), Cambridge University Press, Cambridge MA.

Kydland, F.W. and Prescott, E.C. (1977) 'Rules rather than discretion: the inconsistency of the optimal plans', Journal of Political Economy, 85(3), 473-49.

Neyapti, B. (2001) 'Central bank independence and economic performance in eastern Europe", Economic Systems, 25(4), 381-399.

Rogoff, K. (1985), 'The optimal degree of commitment to an intermediate monetary target', Quarterly Journal of Economics, $100(4), 1169-1189$.

Siklos, P.L. (2002), The Changing Face of Central Banking: Evolutionary Trends since World War II, Cambridge University Press, Cambridge.

Siklos, P.L. (2008), 'No single definition of central bank independence is right for all countries', European Journal of Political Economy, 24(4), 802-816.

Walsh, C.E. (2008), 'Central bank independence', The New Palgrave Dictionary of Economics, Second Edition, Durlauf, S.N. and Blume, L.E (eds), Palgrave Macmillan, Houndmills.

Walsh, C.E. (2003), Monetary Theory and Policy, second edition, MIT Press, Cambridge MA.

Whale, P.B. (1939), 'Central banks and the state', Manchester School, 10(1), 38-49 .

Irina Mădălina Doroftei and Cristian Păun (2013), Journal of Eastern Europe Research in Business and Economics, DOI: 10.5171/2013. 165597. 


\section{Annex - Legal Central Bank Independence Index (CWN) for Romania in} 2012

Weight Score

1.Chief Executive Officer
a. Term of office
b. Appointment of CEO
c. Dismissal
d. Is the CEO allowed to hold any other offices?

0.05

0.05

0.05

0.05

0.5

0.5

0.83

1

\section{Policy Formulation}

a. Who formulates monetary policy

0.05

1

b. Who has final word in resolution conflicts

0.05

0.8

c. Role in Goverment's budgetary process

0.05

0

3. Objectives (price stability)

0.15

0.8

\section{Limitations on lending to Government}
a. Advances
b. Securitized lending
c. Terms of lending
d. Potential borrowers
e. Definition of limits
f. Maturity of loans
g. Interest rates
h. Buying in primary market

$\begin{array}{ll}0.15 & 1 \\ 0.1 & 1 \\ 0.1 & 1 \\ 0.05 & 1 \\ 0.025 & 0.67 \\ 0.025 & 1 \\ 0.025 & 0.75 \\ 0.025 & 1\end{array}$

$1 \quad 0.837$ 